\section{DEMONY HeIAN}

Renata Iwicka, Źródta klasycznej demonologii klasycznej, Wydawnictwo Uniwersytetu Jagiellońskiego, Kraków 2017, ss. 264.

Nakładem Wydawnictwa Uniwersytetu Jagiellońskiego w 2017 r. ukazała się monografia Renaty Iwickiej pt. Źródła klasycznej demonologii japońskiej. Dr Iwicka, absolwentka Instytutu Filologii Orientalnej, specjalizuje się w demonologii oraz w szeroko pojętej kulturze i historii Dalekiego Wschodu. Z punktu widzenia europejskiego badacza, demonologia japońska jest niezwykle bogata i nie ma co ukrywać - egzotyczna. Pojawianiu się sił nieczystych towarzyszą liczne przesądy, rozbudowana symbolika oraz egzorcyzmy, przesiąnnięte tamtejszą kulturą i długimi latami tradycji. Szczególnie interesujący pod tym względem jest okres klasyczny, czyli Heian (VIII-XII w. n.e.), który stanowi podstawe do rozważań w omawianej publikacji. To właśnie w Heian ludzie panicznie bali się demonów i zaczęto nadawać swojemu strachowi pewien, jeszcze nie do końca określony, kształt. Owe istoty były bowiem na tyle rozmyte i niedookreślone, że jeszcze bardziej potęgowały lęk przed nieznanym.

W tym samym roku co publikacja Iwickiej, została wydana praca innego badacza folkloru japońskiego, Amerykanina Michaela Dylana Fostera pt. Yokai. Tajemnicze stwory w kulturze japońskiej. Wspominam o tym nie bez przyczyny - badacz ten wykorzystuje niezwykle szeroką kategorię Yokai (Foster 2017), która pojawiła się w Japonii w epokach późniejszych w stosunku do Heian, zaś rozpowszechniła się szczególnie w Edo (od XVII w. do lat 70. XIX w.)., „Potwory" były już w tym czasie na tyle dookreślone, ,udomowione" i nasiąknięte wpływami kultury zachodniej, że w jednym worku znalazły się duchy, demony, diabły, upiorne zwierzęta, ogry, gobliny oraz wszel-

${ }^{1}$ Teatr no, sztuki teatrów kagura czy kabuki. kie postacie metamorficzne. Ich odzwierciedlenia pojawiały się, między innymi, w drzeworytnictwie czy w sztukach teatralnych ${ }^{1}$, nie pozostawiając zbyt wiele miejsca na niedopowiedzenia. Według Iwickiej:

[...] Człowiek najbardziej boi się tego, czego nie widzi i nie zna, brak opisu demona całkowicie eliminuje zatem możliwość poznania, familiarności, znajomości, pewnego rodzaju uspokojenie. Stwierdzić więc można, że epoki późniejsze [po okresie Heian - przypis autora], zaczynając przedstawiać demony na deskach teatrów, dawały im określona postać, którą w pewien sposób można było zaakceptować i przyjąć do kręgu wyobraźni, co tym samym zniszczyło całkowicie grozę tych istot (Iwicka 2017: 71)

Z powyższego sądu wynika, iż strach musi przybrać określona postać, żeby dało się nad nim zapanować (Mitarski 2012: 163). Dlatego też omawiana przez autorkę epoka jest tak istotna - demony należą jeszcze do sfery natury, która jest nieprzewidywalna i przez to groźna dla człowieka. Łączy się z tym również dychotomia „swój-obcy”, na którą autorka poświęciła dużo miejsca.

Innym powodem, dla którego Iwicka postanowiła zainteresować się epoką Heian, jest fakt, że tak wczesny etap rozwoju Japonii rzadko kiedy brany jest pod uwagę przez badaczy folkloru (s. 13) - okres ten nie cieszy się zbytnią popularnością, dlatego publikacja ta stanowi w pewnym sensie wprowadzenie do wiedzy o demonologii japońskiej na gruncie polskim.

Podstawa źródłową omawianej publikacji są anegdoty $\mathrm{z}$ anonimowego zbioru Konjaku Monogatari, pochodzącego prawdopodobnie z XII wieku, które autorka uzupełnia o treści pojawiajace się $\mathrm{w}$ epokach późniejszych, między innymi w teatrze no, w filmie, komiksie i w legendach współczesnych. Dlaczego takie połączenie? Część z tych watków czerpie z dokonań wcześniejszych epok, w tym z okresu Heian, często „twórczo” je przekształcając. Autorka anali- 
zuje teksty, choć jak sama wskazuje, demonologia przynależy do kultury oralnej. Według niej, monografia ta ,nie jest to [...] tylko i wyłącznie lektura tekstów, ale też próba odczytania znaczeń ukrytych za rytuałami, obrzędami, amuletami, zwyczajami i obrazami" (Iwicka 2017: 18). Czy rzeczywiście tak jest, spróbuję odpowiedzieć w dalszej części recenzji.

Pojawia się podstawowe pytanie: co w istocie stanowi przedmiot jej badań? „Po co zajmować się czymś, co nie istnieje?" (Iwicka 2017: 9) - to budzące kontrowersje zdanie pojawia się już na samym początku wstępu do omawianej publikacji. Autorka wyjaśnia, że interesuje ją przede wszystkim istnienie demonów w kulturze, niekoniecznie zaś ich status ontologiczny. Zamiast więc szukać odpowiedzi na pytanie: ,,czy istnieją?, należałoby raczej szukać odpowiedzi na pytanie: ,jak istnieją?”. Badaczka wyjaśnia:

Najistotniejszym w mojej pracy zagadnieniem jest interakcja świata demonów i ludzi w klasycznej kulturze japońskiej, a więc niejako implicite należy założyć, że badamy to, co istnieje choćby tylko na płaszczyźnie wyobrażeń i szeroko rozumianego życia duchowego (Iwicka 2017: 9).

Dominantą tematyczną tej monografii będzie więc zwrócenie uwagi na przenikanie się świata ludzkiego i demonicznego. By móc w ogóle o tym mówić, Iwicka tworzy kategorię „bańki czasoprzestrzennej” (inaczej buforu), w którym nakładają się dwie różne rzeczywistości - ludzka i nadnaturalna (Iwicka 2017: 14). Termin „bańki czasoprzestrzennej”, choć może nie brzmi zbyt przekonująco, okazuje się być zagadnieniem niezwykle obiecującym, które po wyjaśnieniach autorki daje się obronić. Iwicka - jak zapowiada - pozostawia na boku kwestie ontologiczne, a skupia się na typowo ludzkim, wyobrażeniowym aspekcie tego zjawiska w kulturze. Temat bańki czasoprzestrzennej rozwinę jednak w dalszej części recenzji. Na zakończenie wstępu pojawiają się zaś pytania konstytutywne dla omawianej publikacji - co się dzieje z przestrzenia i czasem, gdy istoty nieprzynależące do danego terytorium naruszą tabu miejsca? Czy demony japońskie, tak jak w europejskim rozumieniu tego słowa (Iwicka 2017: 207), dotyczą tylko i wyłącznie siły wrogiej człowiekowi, czy może istnieją demony neutralne, a nawet przyjazne człowiekowi? (Iwicka 2017: 21) Te zagadnienia stanowia dużą część omawianej tutaj pracy.

Rozdział pierwszy, zatytułowany „Wokół Heian" (Iwicka 2017: 27), badaczka poświęca historycznemu kontekstowi epoki. Dowiadujemy się, między innymi, jak wyglądała kwestia religijności w głębokim japońskim średniowieczu oraz czym charakteryzowało się tamtejsze społeczeństwo. Nie dziwi fakt, że opisywany świat należał do arystokracji - to właśnie wśród najwyższej warstwy społecznej było najwięcej osób uczonych. Niekoniecznie jednak byli to ludzie najwyżej urodzeni, czego przykładem mogą być egzaminy państwowe, do których mógł podejść niemal każdy (Iwicka 2017: 30), choć tak naprawdę bez odpowiednich kontaktów niewielu miało szansę na ostateczny sukces. Mowa tu tylko o mężczyznach, bowiem kobiety miały o wiele trudniej, biorąc chociażby pod uwagę popularne wśród arystokracji tamtych czasów układy poligamiczne (Iwicka 2017: 33). Bieda nie interesowała ludzi piśmiennych, więc świat istot nadprzyrodzonych musiał być omawiany $\mathrm{z}$ pozycji arystokracji. Żebracy i wszyscy inni osobnicy wyłączeni ze społeczeństwa (obcy) mogli być jednocześnie kojarzeni ze sferą demoniczną i tylko w takiej postaci pojawiali się na kartach historii.

Powszechna poligamia pociągała za sobą groźbę zdrady i zazdrości:

Nawet Yugiri z powieści Genji monogatari był zmuszony do tego, aby wziąć drugą żonę, pod naciskiem opinii znajomych, rodziny i właściwego mu kręgu społecznego. Los kobiet nie przedstawiał się zatem jako godny pozazdroszczenia. Zdarzało się, że po śmierci męża nie dostawały żadnej części majątku lub musiały o niego walczyć z innymi spadkobiercami i czekało je trudne życie. Właśnie w tym upatruje się przyczyny takiej popularności wiary $\mathrm{w}$ onryo, czyli gniewne duchy, zwłaszcza duchy kobiet [...] (Iwicka 2017: 34). 
Wszystkie te cechy (oraz krew menstruacyjna będąca elementem tabu shintoistycznego; Iwicka 2017: 184), przyczyniły się do tego, że właśnie kobietom przypisywano cechy demoniczne. Mogły więc pojawiać się one po drugiej stronie, czyli po stronie świata paranormalnego.

Do grupy istot nadprzyrodzonych mogli dołączyć również zmarli władcy i książęta. Autorka przytacza przykłady, w których duchy poprzednich namiestników gnębiły dwór (przypisywano im wszelkie zło), więc próbowano temu przeciwdziałać - bywało, że pośmiertne deifikacje miały zadośćuczynić zagubionym duszom (Iwicka 2017: 28). Opisywane zdarzenia miały zazwyczaj miejsce na dworze cesarskim, a więc $\mathrm{w}$ środowisku niezwykle ważnym dla funkcjonowania całego państwa. Tym większy strach wywoływały, ponieważ okazywało się, że dla istot nadprzyrodzonych nie ma rzeczy świętych i mogą działać niemal wszędzie.

Ważną rolę w kształtowaniu się wierzeń związanych ze sferą nadprzyrodzoną miała religia. Shintoizm, czyli tradycyjna religia japońska, wymieszała się bowiem z nowoczesnym i niezwykle dogmatycznym buddyzmem, który przywędrował do Japonii z jednego z królestw koreańskich w VI w. n.e. Buddyzm, początkowo religia uczonych, potrzebował czasu, by stać się najpopularniejszym wyznaniem Japończyków. Jego struktura oraz złożona sfera obrzędowości (w odróżnieniu od shinto) niezwykle dobrze dopasowała się do bogatej sfery demonicznej, pozwalając odnaleźć nowe sposoby radzenia sobie $\mathrm{z}$ demonami. Można powiedzieć, że buddyzm zmonopolizował sferę egzorcyzmów, ale i nadał lękowi przed istotami demonicznymi określony kształt:

Buddyjscy kapłani nadali formę tym niewidzialnym bytom i objaśnili oni jako jaki, którzy zbuntowali sie przeciwko Buddzie. Również kapłani wykonywali rytuały, które miały odpędzić oni [...]. Buddyzm przejął obowiązek egzorcyzmowania tych przerażających istot za pomocą inkantacji i modlitw. Buddyzm był cywilizacją, która dysponowała siłą, by niewidzialne uczynić widzialnym, a także miała środki dialogu oraz walki z niewidzialnym (Iwicka 2017: 176).
Jak wskazuje badaczka, powyższa wypowiedź Reidera, cytujacca słowa Osumi'ego Kazuo, nie miałaby racji bytu w okresie klasycznym, gdyż z demonami Heian nie dało się negocjować. Owe istoty zagarniały bowiem wszystko, co chciały (wynikało to z sił naturalnych) $\mathrm{i}$ dopiero rozwój buddyzmu doprowadził do uładzenia i niejako oswojenia tychże istot (Iwicka 2017: 176). Ale to nie wszystko - w epoce klasycznej ważną rolę pełniła również filozofia taoistyczna. Przy Ministerstwie Spraw Wewnętrznych istniało bowiem biuro On'yoryo, które zajmowało się nie tylko odpędzaniem złych duchów, walką z demonami, oczyszczaniem terenu i ochroną, ale również układaniem kalendarza oraz geomancja (Iwicka 2017: 40). Zinstytucjonalizowanie yin i yang świadczyło o dużej przesąności, związanej chociażby z kierunkami świata czy miejscami korzystnymi i niekorzystnymi. W takich sytuacjach łatwo było powiązać konkretne miejsca, a nawet czynności ze sferą demoniczną:

Prócz nieszczęśliwych dni miesiąca, podobnie pechowe mogły być kierunki świata, a także pewne miejsca, konkretna brama, znana rezydencja czy też budynek w obrębie rezydencji. Co należało w takim wypadku robić? Pod żadnym pozorem nie wolno było udawać się w tym kierunku. Jeśli urzędnik miał przybyć do rezydencji pewnego ministra, a rezydencja leżała na przykład na północ od jego własnego domu, a północ akurat $\mathrm{w}$ tym czasie była kierunkiem niepomyślnym, musiał on okrążyć ją w taki sposób, by ominąc feralny kierunek (Iwicka 2017: 41).

Autorka publikacji podkreśla niezwykle ważną kulturową rolę języka japońskiego. Okres Heian jest bowiem czasem japonizacji kultury, próbą zamknięcia się na Chiny $\mathrm{i}$ inne sąsiednie kultury oraz skupienia się na własnej architekturze i sztuce, w tym również na języku. Choć język chiński był językiem urzędniczym, swoistym lingua franca tamtych czasów, to popularność zaczał zyskiwać język japoński. W chińskim funkcjonowały przede wszystkim wszelkie przekazy buddyjskie, zaś domeną japońskiego stały się treści świeckie i rodzime dla Japończyków (Iwicka 2017: 44). Niezwykle ważną rolę w rozwoju tego języka odegrały 
kobiety - chiński jako dialekt dworski był domeną mężczyzn, za to kobiety posługiwały się czystym japońskim i to właśnie im przypisuje się tworzenie pierwszych utrwalonych w ten sposób wspomnień.

Powróćmy jeszcze na chwilę do wizerunków demonów z epoki Heian - postacie takie pojawiały się chociażby na malarskich zwojach zwanych Emakimono (Iwicka 2017: 52). Proste przedstawienia tamtejszych istot pobudzały wyobraźnie i lęk. Jak zauważa autorka, przedstawienia epok późniejszych były zbyt dookreślone, by móc straszyć z taką mocą, jak w epoce klasycznej. „Demony powróciły” w epoce Edo, chociażby pod postacią kaidan (opowieści grozy), ale narracje te służyły już innym celom. Współcześnie wątki kaidan przedstawiane sa w ramach innych form literackich, w komiksie, filmie fabularnym oraz $\mathrm{w}$ japońskiej animacji, w pewnym stopniu ,oddemonizowując" świat pozazmysłowy poprzez wprowadzenie elementów gore ${ }^{2}$.

Jeden z najobszerniejszych rozdziałów monografii poświęcony jest typologii i genezie istot nadnaturalnych (Iwicka 2017: 53). Sama autorka wyjaśnia tę kwestię następująco:

Przy omawianiu problematyki istot świata pozaludzkiego warto podjąć próbę ich usystematyzowania z uwagi na brak jakiejkolwiek satysfakcjonującej klasyfikacji w polskojęzycznej literaturze przedmiotu [...]. Typologia, która chciałabym zaproponować, ma oczywiście wadę - jak każda klasyfikacja - to znaczy dokonuje sztucznego, niekiedy zawężającego czy upraszającego podziału, pozwala jednak na zorientowanie się w specyfice istot pozaziemskich [...]. Wszystkie istoty demonologii klasycznej należą do konkretnych grup, które zostały przeze mnie na potrzeby niniejszych rozważań utworzone, a przynależność tę warunkują pewne wspólne cechy [...]. I tak jako pierwsza zostanie omówiona grupa określana jako demony, a następnie duchy wszelakiego typu. Kolejna grupa zawiera rozmaite zjawiska niewyjaśnione, po niej zostaną omówione zwierzẹta, a na

${ }^{2}$ Przykład: film Nobuo Nakagawy Opowieść o duchach z Yotsui (1959). samym zaś końcu - istoty należące do sfery magii taoistycznej (Iwicka 2017: 64-65).

$\mathrm{W}$ rozdziale tym Iwicka przedstawia koncepcje zaświatów, które pojawiały się w wyobrażeniach ludzi tamtych czasów, zwracając szczególną uwagę na ważne i nie dające się uniknąć zawiłości językowe (jak odczytywanie ideogramów i fonetyki). Różne wieloznaczności pojawiają się już w przypadku „krainy ciemności” - słów Yomi no kuni, które w zależności od użytych znaków mogą znaczyć co innego, mogą zostać zupełnie inaczej odczytane, narzucając inną drogę interpretacji (Iwicka 2017: 54). Mamy więc do czynienia z problemem wielopłaszczyznowym, ponieważ nie da się mówić o japońskich demonach, pomijając aspekt lingwistyczny. Nazwy demonów, jak zauważa autorka, nie zawsze sa jasne. W oryginalnym tekście dotyczącym Oni (istot wyjątkowo niebezpiecznych) brak jest adnotacji fonetycznych (furigany), stąd trudno powiedzieć, jak w rzeczywistości odczytywano znaki. Wiadomo było jedynie tyle, że miały wywoływać przerażenie (Iwicka 2017: 66). Uwikłanie w kontekst sytuacyjny również nie ułatwia zadania badaczom japońskiego folkloru - demony i inne istoty nadprzyrodzone charakteryzują się bowiem dużą wariantywnością. W przypadku Kitsune (lisów figlarzy), jeden z przywołanych przez Iwicką badaczy wskazuje, iż istniało trzynaście rodzajów lisów, dysponujących różnymi mocami (zmiennokształtność, opętania itd.), a nawet różniących się ranga - były bowiem Kitsune pospolite, jak i Kitsune wysokiej klasy (Iwicka 2017: 106). W Japonii istnieje również tabu słów (tzw. kotodama), których odczytanie wymaga dużej znajomości języka oraz kultury Kraju Kwitnącej Wiśni:

Niektóre liczby są nieszczęśliwe [jak cztery, która fonetycznie brzmi tak samo jak słowo »śmierć«], inne z kolei uważa się za przynoszące szczęście [jak osiem][...]. Za przekonaniem o nieszczęśliwych latach w życiu nie stoi czasami nic prócz zbieżności fonetycznej wyrazów, co z kolei może 
łączyć się z powszechnym, nie tylko w Japonii, tabu słów [kotodama]. Może to być rozciągnięcie warstwy semantycznej jednej klasy słów na inne i przeniesienie lęku, jaki wywołują, na podobnie brzmiące wyrazy (Iwicka 2017: 171-172).

Należy zaznaczyć, iż autorka w przystępny sposób wyjaśnia wszelkie kwestie lingwistyczne - w przypisach znajdujemy rozwinięcia i thumaczenia pojęć, które nie zmieściły się w tekście głównym, zaś wszelkie teksty obcojęzyczne autorka przetłumaczyła na język polski. Doświadczenia badaczki z językiem japońskim zaowocowały tekstem spójnym i zrozumiałym dla szerszego grona odbiorców.

Autorka szeroko traktuje całą sferę demonologiczna, dlatego w jej ramach wspomina między innymi o duchach błądzących oraz o tych idacych w zaświaty. Do bliżej nieokreślonych zaświatów miałyby trafiać dusze ludzi, którzy istnieja jeszcze w pamięci żyjących, zaś wszystkie inne stawałyby sie duchami wędrujacymi (stą widoczny nawet we współczesnej Japonii nacisk na posiadanie potomstwa - osoba posiadająca rodzine nie musiałaby martwić sie o swój los po śmierci, gdyż miałaby kogoś, kto zatroszczyłby się o godne przeprowadzenie jej na tamten świat; Iwicka 2017: 115). W czasach szerzących się epidemii, duchom powracającym $\mathrm{z}$ zaświatów przypisywano działania na niekorzyść człowiekowi - z zemsty sprowadzających wszelkie choroby (Iwicka 2017: 80). Japończycy mieli specyficzny sposób radzenia sobie $\mathrm{z}$ takimi zjawiskami - tego typu duchów nawet nie starano się karać czy odstraszać, próbowano zaś zdobyć ich przychylność, tworząc poświęcone im świątynie. Podobne praktyki istnieją do dziś - przykładem może być świątynia Yasukuni, w której współcześnie oddaje się hołd wszystkim poległym za ojczyznę żołnierzom, by ich duchy nie mściły się za doznaną krzywdę. Jest to o tyle kontrowersyjny przykład (na co zwraca uwage badaczka), że w Yasukuni czci się również zbrodniarzy wojennych, osądzonych i skazanych po II wojnie światowej. Nie przeszkadza to jednak w tym, by świą- tynię co jakiś czas odwiedzali najwyżsi dygnitarze państwowi, na czele z obecnym premierem Japonii Abe Shinzo (Iwicka 2017: 78). Należy jednak brać pod uwagę, że praktyki polegające na oddawaniu czci wszystkim duchom, nawet tym złym, „,mają swoje podstawy w wierzeniach związanych z goryo (duchami mściwymi - przypis autora) i wynikają z obaw, że takie osoby, jak generał Tojo Hideki (zbrodniarz wojenny, nazywany Hitlerem Dalekiego Wschodu - przypis autora), mogłyby powrócić, by się mścić za skazanie na karę śmierci" (Iwicka 2017: 78). Jest to więc tradycja bardzo mocno zakorzeniona $\mathrm{w}$ wierzeniowości Japończyków.

W kulture Kraju Kwitnacej Wiśni silnie wpisana jest również dychotomia „swójobcy". Nawiązania do niej pojawiają się już w momencie, gdy podejmiemy się analizy terminu ikai, chociaż jest to pojęcie dość skomplikowane (Iwicka 2017: 63), to w najprostszym rozumieniu oznacza ,inny świat”. Innym światem może być w tym przypadku chociażby dom sasiada czy inna wioska. Stąd mamy już blisko do znanej nam z własnego podwórka definicji obcego (Burszta 1998: 13). Co ciekawe - w odróżnieniu od takai, czyli zaświatów, do których trafiają duchy zmarłych, ikai jest miejscem, z którego przybywają istoty nadnaturalne (czyli wszelkie omawiane tutaj demony). Ikai wyjaśnia więc, gdzie znajdują się demony, gdy akurat nie naprzykrzają się ludziom (Iwicka 2017: 64).

W okresie klasycznym konstrukt ,swójobcy" przenoszony bywał na prymitywne plemiona, które były podbijane przez bohaterów opisywanych w podaniach. Plemiona te były obce, utożsamiano je więc z siłami nieczystymi, ze sferą demoniczną. Kiedy bohaterowie wybierali się, by pokonać $T s u$ chigumo, legendarnego pająka ziemnego, to najprawdopodobniej rozprawiali sie z wrogimi im plemionami (które tak jak pająki zamieszkiwały jamy w ziemi) (Iwicka 2017: 105). Wszystko więc odbywało się na zasadzie analogii i skojarzeń. Chyba najlepszym podsumowaniem tego wątku będą słowa Iwickiej: 
Wyobraźnia japońska stworzyła imponujacy zbiór wszelkiego rodzaju »obcości«, a wyobrażenia owe nie znalazły swojego kresu ani w chwili ustanowienia państwa, ani nawet na początku XX wieku, gdyż w dalszym ciągle żywy był koncept ijin, czyli »innego«, »obcego«. To określenie mogło oznaczać na przykład mieszkańca innej wioski, obcokrajowca czy też budzące grozę bóstwo zamieszkujące »obce« tereny. Do dziś w kulturze japońskiej można łatwo wyodrębnić jeden szczególny paradygmat: »my«-»oni«, który od zawsze stanowił jedną $\mathrm{z}$ ważnych osi kultury japońskiej (Iwicka 2017: 105).

Zagadnieniu czasu i miejsca wystepowania istot nadnaturalnych poświęcony został rozdział trzeci. To właśnie tutaj autorka rozwija swoją definicję bańki czasoprzestrzennej, w której spotykałyby się dwa światy - ludzki i nadprzyrodzony, tworząc nową, trzecią rzeczywistość. Miejsce buforowe zostało przez badaczkę nazwane „bańką”, ponieważ jego przestrzeń jest nietrwała (obca istota może się w niej pojawiać i znikać). Do zilustrowania tego zjawiska autorka wykorzystała dwa diagramy - jeden przedstawiający konstrukcję bufora przestrzennego a drugi - bufora czasowego (Iwicka 2017: 126, 132).

Łącznikiem pomiędzy obiema strefami, zarówno czasową, jak i przestrzenną jest »bufor« - moment lub miejsce liminalne należące i nienależące jednocześnie do obu światów, w którym ulegają zmieszaniu natury ich obu. To właśnie odróżnia je od limesu - stanowią połączenie obu światów, tworząc nowy, choćby momentalny. W przeciwieństwie jednak do miejsca czy czasu dokładnie określonego jako sprzyjającego siłom nadprzyrodzonym [na przykład noc czy nawiedzone miejsce] bufor ma nature płynna, trudna do uchwycenia i tym samym najbardziej niebezpieczną (Iwicka 2017: 142)

W klasycznej, tradycyjnej wierzeniowości naruszenie owego bufora niosło za sobą katastrofalne skutki, było bardzo niebezpieczne (Iwicka 2017: 113). Z oczywisty

${ }^{3}$ Nawiązanie do tytułu jednej z rycin hiszpańskiego artysty Francisca Goi z końca XVIII wieku. względów termin ten powiązany jest $\mathrm{z}$ charakterystyką miejsc opuszczonych, zrujnowanych, będących granicami, jak mosty, rzeki czy bramy (Iwicka 2017: 111). Bańki powstawały na granicy natury i cywilizacji, choć często były to miejsca przejęte niejako przez siły naturalne. Demony przynależą do tego świata i z tego też względu pozbawione są moralności - kieruje nimi raczej instynkt i pierwiastek nieprzewidywalności, który potęgował przerażenie u każdego, kto miał z nimi kontakt. Z oczywistych względów istoty nadprzyrodzone miały coraz mniej miejsca - im większy bowiem postęp technologiczny, tym mniej przyrody i przestrzeni o niedookreślonej przynależności. Świat istot demonicznych znajdował się bardzo blisko miejsc ludzkiego bytowania, być może wynikało to ze stosunkowo niewielkiej liczby wyobrażeń zaświatów w wierzeniach Japończyków. Bóstwa shintoistyczne mieszkały bowiem jak ludzie i zachowywały się jak ludzie. Brak nagrody za dobre życie oznaczałby w tym przypadku brak wyobrażeń zaświatów jako takich. Miejsce bytowania dusz było więc niedookreślone (Iwicka 2017: 56). Autorka czyni dodatkowo jedno ważne spostrzeżenie - natura tylko do pewnego stopnia daje się ucywilizować i sfera nocy prawdopodobnie na zawsze pozostanie już czasem demonów (Iwicka 2017: 197), bowiem „gdy rozum śpi, budzą się demony"3.

W czwartym rozdziale monografii Iwicka opisuje amulety, obrzędy rytualne oraz wszelkie inne sposoby radzenia sobie $\mathrm{z}$ istotami demonicznymi. Dowiadujemy się między innymi tego, iż przedmioty wykonane $\mathrm{z}$ metalu mogły przeciwdziałać złym mocom, chociażby groty strzał wykonane $\mathrm{z}$ tego materiału. Strzały były artefaktem pozytywnym (Iwicka 2017: 164), „bronią na potwory”, współcześnie zaś mogą być symbolem przyjaźni i niezłomności ${ }^{4}$. Również 
w kulturze japońskiej istnieja pewne uniwersalizmy znane globalnie, jak np. woda mająca właściwości oczyszczające (Iwicka 2017: 184).

Ostatni rozdział publikacji dotyczy demonów pojawiających się w epokach późniejszych w stosunku do okresu klasycznego, autorka przywołuje tutaj różne gałęzie kultury, w których najpełniej zarysowują się elementy z niezwykle bogatej demonologii japońskiej, między innymi: teatr, opowiadania Kaidan, a nawet współczesną japońską animację. Iwicka dokonuje krótkiej analizy dzieła Hayao Miyazaki'ego pt. Księżniczka Mononoke (1997), w której zwraca baczną uwagę na zarysowaną przez Miyazaki'ego problematykę zderzenia cywilizacji z naturą, oraz typy postaci buforowych, a nawet trawersyjnych (s. 229), czyli takich, które mogą przekraczać barierę pomiędzy światem ludzkim i nadprzyrodzonym bez większych trudności.

Autorka przywołuje kontekst globalny, by móc osadzić wierzeniowość japońską w wymiarze ogólnoświatowym. Dzięki temu możliwe staje się zaobserwowanie zjawisk o charakterze uniwersalnym na gruncie japońskim oraz tych, które przynależą kulturowo do Japonii (i nieco szerzej - do kręgu kultur wschodnioazjatyckich). Iwicka w taki sposób komentuje współczesne japońskie nawiązania do kultur obcych:

Japończycy chętnie czerpią w przypadku demonologii i ogólnie religii z innych systemów i kręgów cywilizacyjnych, zdaje mi się jednak, że jedyny aspekt, jaki przenosza, jest wizualny. Innymi słowy - zapożyczają artefakty bez tła ideowego. Oczywiście sa wyjątki i podobna generalizacja może się wydawać niesprawiedliwa, jest to jednak jeden $\mathrm{z}$ wniosków, jaki wypływa z dziesiątków przykładów (Iwicka 2017: 233).

Podobne wnioski można wyciągnąć, przyglądając się współczesnym zjawiskom folklorystycznym (być może należałoby operować tutaj terminami folkloryzmu albo

strzałę łatwo jest złamać, ale gdy jest ich więcej, nie jest to już takie proste. nawet pseudofolkloru), gdyż współcześnie tworzone bestiariusze i klasyfikacje demonów oparte są na autorskich kreacjach yokai i dużo zapożyczaja z innych kregów kulturowych ${ }^{5}$. Dla przykładu, do podobnych zbiorów dołącza się dziś postacie wampirów, które ze względu na tabu krwi nie znalazłyby się w demonologii klasycznej oraz postacie teriantropiczne (ludzi zamieniających się w zwierzęta - w okresie Heian możliwe było przeistoczenie się zwierzęcia w człowieka, ale nie na odwrót). Współczesna demonologia japońska czerpie treści $\mathrm{z}$ bogatego dorobku cywilizacyjnego, ale jednocześnie dokłada swoje własne elementy, zwracając niemałą uwagę na kwestie językowe. To właśnie język japoński w dużej mierze definiuje folklor japoński, o czym była już mowa. Współczesne demony staja się czasami bohaterami bajek dla dzieci (Iwicka 2017: 196), jest to więc jeszcze jeden sposób na radzenie sobie z lękami. Gdyby to nie wystarczyło - demony dużo bardziej przypominają dziś postacie ludzkie, ze swoimi problemami emocjonalnymi i egzystencjalnymi. Mają więc raczej wywoływać współczucie bądź odwoływać się do symboliki uczuć, zazwyczaj tych najbardziej gwałtownych (Iwicka 2017: 201).

Źródła klasycznej demonologii japońskiej to pozycja niezwykle interesująca przede wszystkim z powodu skupienia sie autorki na jednym z najciekawszych okresów folkloru japońskiego, epoce Heian. Jak podkreśla, był to czas panicznego lęku przed demonami:

Imaginarium japońskiego okresu klasycznego było mocno splątane i niejasne. Pewne idee wpływały na inne, zaciemniajac, rozmywajac i w rezultacie uniemożliwiając pełną rekonstrukcję postaci czy też problemu. Niektóre wyobrażenia powstały przez nałożenie się kilku tradycji, niemożliwe jest więc podanie jednego źródła. Demoniczny panteon japoński nie miał nawet swojej nazwy, dopiero epoki późniejsze ukuły, na wzór chiński,

\footnotetext{
${ }^{5}$ Przykład - zbiór Kwaidan. Opowieści niesamowite autorstwa Lafcadia Hearna, Bydgoszcz 2008.
} 
określenie yokai - czyli wszystko to, co budziło przerażenie (Iwicka 2017: 109).

Analiza przebogatej demonologii japońskiej nie byłaby możliwa, gdyby autorka nie znała dobrze tradycji i zwyczajów tamtejszej kultury. W interpretacji japońskich treści w pewnym stopniu pomaga znajomość naszej rodzimej, europejskiej kultury, bowiem niektóre zjawiska mają zasięg globalny i wynikają z naturalnych właściwości świata (np. oczyszczająca rola wody). Po lekturze publikacji, ,imaginarium japońskiego okresu klasycznego" nadal wydaje się dość mgliste, choć autorka w ciekawy sposób przedstawiła chyba najważniejsze zagadnienie niniejszej pozycji, a mianowicie przenikanie się świata ludzkiego i nadprzyrodzonego. Współczesne wyobrażenia demonów zasługują według autorki na oddzielną analizę, więc dużą skrótowość rozdziału ostatniego można jej wybaczyć. Tematami do dalszych rozważań są według Iwickiej kwestie związane $\mathrm{z}$ rozbudową demonologii $\mathrm{w}$ okresie Edo oraz demonologią pojawiającą się we współczesnej popkulturze. Praca związana $\mathrm{z}$ tym drugim zagadnieniem mogłaby stanowić ważną pozycję w badaniach nad współczesnymi kulturami Dalekiego Wschodu.

MATEUSZ NAPIÓRKOWSKI Uniwersytetu Mikołaja Kopernika w Toru-

\section{BIBLIOGRAFIA}

BuRsZTA, W. (1998). Antropologia kultury. Poznań: Wydawnictwo Zysk i S-ka.

FOSTER, M. D. (2017). Yokai. Tajemnicze stwory w kulturze japońskiej, Kraków: Wydawnictwo Uniwersytetu Jagiellońskiego.

IWICKA, R. (2017). Źródła klasycznej demonologii klasycznej, Kraków: Wydawnictwo Uniwersytetu Jagiellońskiego.

MitARSKI, J. (2012). Demonologia lęku. W: Kępiński. A. (2012). Lęk, Kraków: Wydawnictwo Literackie. 